\title{
Urgensi Penguatan Kesadaran Pelajar tentang Perannya sebagai Hamba Allah untuk Mengatasi Perilaku Tercela
}

\author{
Dera Nugraha $^{1 \bowtie}$, Nurwadjah Ahmad $^{2}$, \& Andewi Suhartini ${ }^{3}$ \\ ${ }^{123}$ Universitas Islam Negeri Sunan Gunung Djati Bandung \\ $凶$ nugrahadera1@gmail.com

\begin{abstract}
This study aims to find the causes of akhlak madzmumah (despicable behavior) among students as well as to present the idea of a solution. By employing the literature review method, the results of this study indicate that the cause of the many occurrences of such morals is due to Tauhid (Islamic monotheism) education that has not touched the awareness of students, especially about the nature of their main role as a servant of Allah. Humans as special creatures have provisions as well as additional tasks, namely fitrah and ibadah. Fitrah cannot guarantee that humans become good people by themselves, because some negative things around them can cover them up, so that the education is needed to help humans to always cling to and develop their nature. It is also important to strengthen ibadah so that one can act as a true servant of Allah. Thus, despicable behavior can be avoided by students on the basis of this awareness.
\end{abstract}

Keywords: Consciousness, fitrah, role, servant of Allah, student.

Abstrak: Penelitian ini bertujuan untuk menemukan penyebab timbulnya akhlak madzmumah (perilaku tercela) di kalangan pelajar sekaligus menyuguhkan gagasan solusinya. Dengan menggunakan metode kajian pustaka, hasil penelitian ini menunjukan bahwa penyebab masih banyak terjadinya perilaku tercela adalah karena pendidikan Tauhid yang belum menyentuh kesadaran peserta didik, utamanya tentang hakikat peran utama mereka sebagai seorang hamba Allah. Manusia sebagai makhluk istimewa memiliki bekal sekaligus tugas tambahan, yakni fitrah dan ibadah. Fitrah tidak dapat menjamin manusia menjadi orang baik dengan sendirinya, karena beberapa hal negatif di sekelilingnya bisa menutupi, maka di sanalah pendidikan diperlukan untuk membantu manusia agar selalu berpegang teguh dan mengembangkan fitrahnya. Penting juga untuk memperkuat ibadah dan menjauhi segala perbuatan yang menimbulkan dosa agar dapat berperan sebagai hamba Allah yang sesungguhnya. Dengan demikian, perilaku tercela dapat dihindari para pelajar atas dasar kesadaran tersebut.

Kata kunci: Fitrah, hamba Allah, kesadaran, pelajar, peran. 
Urgensi Penguatan Kesadaran Pelajar tentang Perannya sebagai Hamba Allah...

Dera Nugraha, dkk

\section{Pendahuluan}

Pesatnya perkembangan ilmu pengetahuan dan teknologi dan perubahan sosial tidak sepenuhnya kondusif bagi tujuan pendidikan. Hal ini ditunjukkan dengan munculnya dampak negatif berupa lahirnya perilaku menyimpang yang ada pada peserta didik diakibatkan oleh serangan gencar narkoba, LGBT (lesbian, gay, biseksual, dan transgender), ideologi radikal dan liberal. ${ }^{1}$ Penurunan rasa hormat anak kepada orang tua dan guru, peningkatan tindak kekerasan dan pertengkaran di kalangan pelajar, peningkatan penyalahgunaan narkoba, penurunan semangat belajar, meningkatnya kebiasaan hedonis, dan perluasan perilaku bebas, adalah dampak lain perkembangan ilmu pengetahuan yang pesat dan sudah menjadi pemandangan biasa di kalangan peserta didik. Perilaku ini sangat tidak sesuai dengan tuntunan akhlakul karimah dalam Islam. Hal tersebut terjadi tidak hanya di sekolah umum, tetapi juga terjadi di madrasah yang notabene merupakan sekolah Islami. Hasbi ${ }^{2}$ mengungkapkan bahwa hakikat dari problematika riil yang terjadi di tengah pendidikan agama dan madrasah adalah mulai menggejalanya dekadensi moral, tawuran pelajar, sampai kebebasan seksual.

Berita yang dimuat harian umum Pikiran Rakyat edisi 5 September $2018^{3}$ cukup mengejutkan di kalangan pendidik. Bahwa di Kabupaten Cianjur Jawa Barat, pelajar tingkat SMP menjadi penyumbang jumlah penderita HIV/AIDS sebesar 10-20 persen. Kondisi tersebut diperburuk dengan bertambahnya korban narkoba dan jumlah LGBT dari kalangan yang sama, pelajar. Sepanjang 2019 terdapat 168 orang penderita HIV/AIDS baru, 71 di antaranya dari kalangan LGBT. Belum ada aturan resmi tentang LGBT di Indonesia selama ini pada tingkat nasional, meski begitu terdapat beberapa daerah di Indonesia seperti Banda Aceh dan Palembang telah membuat peraturan mengenai larangan perzinaan dan LGBT termasuk di dalamnya. ${ }^{4}$

Kondisi dimaksud di atas dapat menjadi salah satu bukti pentingnya penguatan kesadaran peserta didik tentang hakikat tujuan Allah menciptakan makhluk-Nya, sebagai bagian dari pendidikan Tauhid. Penguatan kesadaran akan hakikat penciptaan manusia akan mempengaruhi kesadaran perilaku seorang muslim akan pentingnya akhlakul karimah dan senantiasa berupaya menjauhi perilaku tercela.

Terdapat beberapa kajian yang telah membahas tauhid dan korelasinya dengan perilaku peserta didik sebelumnya. Di antaranya Nurfalah ${ }^{5}$ mengenai urgensi pendidikan Tauhid dalam keluarga yang menyebutkan bahwa pendidikan Tauhid akan berpengaruh besar terhadap pembentukan sikap dan perilaku seseorang dalam kehidupan sehari-hari. Hasbi ${ }^{6}$ mengetengahkan bahwa penguatan ketauhidan merupakan dasar paling fundamental dari seluruh hakikat

${ }^{1}$ Tobroni dkk, Memperbincangkan Pemikiran Pendidikan Islam (Prenadamedia Group, 2018).

${ }^{2}$ M Hasbi, "Konsep Tauhid Sebagai Solusi Problematika Agama Bagi Siswa Madrasah," Insania 14 No. 2 M, no. 2 (2009): 289-319.

3 Shofira Hanan, "Pelajar Dari Tingkat SMP Jadi Peyumbang Bertambahnya Penderita HIV/AIDS," Pikiran Rakyat, September 2018. https://www.pikiran-rakyat.com/jawa-barat/pr-01300957/pelajar-dari-tingkat-smp-jadipeyumbang-bertambahnya-penderita-hivaids-429782 (Diakses 22 Agustus 2020).

4 Ramadhani Ramadhani, "Pendidikan Akidah Akhlak Sebagai Solusi Pencegahan LGBT," Al-Adabiya: Jurnal Kebudayaan Dan Keagamaan 15, no. 01 (2020): 47-68, https://doi.org/10.37680/adabiya.v15i01.223.

5 Yasin Nurfalah, "Urgensi Pendidikan Tauhid Dalam Keluarga," Jurnal Pemikiran Keislaman 25, no. 2 (2014): 338-47, https://doi.org/10.33367/tribakti.v25i2.190.

${ }^{6}$ Hasbi, "Konsep Tauhid Sebagai Solusi Problematika Agama Bagi Siswa Madrasah." 
kebutuhan jiwa pendidikan dan diri peserta didik, di tengah fakta dekadensi moral, tawuran, dan kebebasan seksual yang terjadi di kalangan peserta didik madrasah dewasa ini.

$\mathrm{Kamal}^{7}$ mengutarakan, seharusnya keyakinan seseorang yang bertumpu pada tauhidullah memancarkan nilai-nilai sosial. Dimaksudkan agar tauhid Uluhiyah dan Rububiyah bisa tercermin dalam kedataran pergaulan sosial. Artinya pemahaman seseorang terhadap tauhid secara mendalam akan mempengaruhi perilakunya dalam kehidupan bersosial.

Beberapa kajian tersebut juga membahas urgensi penguatan pendidikan tauhid sebagai solusi merebaknya perilaku tercela di kalangan peserta didik. Perbedaannya terletak pada dua hal. Tulisan ini fokus pada penguatan kesadaran tentang peran manusia sebagai hamba Allah Swt. sebagai bagian dari pendidikan Tauhid. Kemudian tulisan ini melibatkan variabel peran manusia secara sosiologis sebagai pendukung gagasan bahwa penguatan kesadaran peserta didik tentang peran utamanya sebagai hamba Allah akan mempengaruhi perilaku mereka dalam menjauhi perilaku tercela.

\section{Metode Penelitian}

Studi pustaka merupakan metode yang digunakan dalam penelitian ini yang dielaborasi dengan pengalaman penulis selama beraktifitas di dunia pendidikan, serta informasi mengenai fakta-fakta yang berkaitan dengan pembahasan. Penulis mengumpulkan, menyeleksi, dan menganalisa tulisan-tulisan terkait urgensi pendidikan tauhid. Kemudian melakukan wawancara dengan beberapa guru dan kepala sekolah terkait isu kenakalan peserta didik. Dilengkapi dengan berbagai informasi media terkait dengan kenakalan peserta didik.

\section{Konsep Kesadaran}

Kesadaran (consciousness) dalam Oxford English Dictionary (OED) memiliki beberapa arti; (a) pengetahuan bersama (b) pengetahuan atau keyakinan internal (c) keadaan mental yang sedang menyadari sesuatu (awareness), (d) mengenali tindakan atau perasaan sendiri (direct awareness), (e) kesatuan pribadi yaitu totalitas impresi, pikiran, perasaan yang membentuk perasaan sadar dan (f) keadaan bangun/terjaga secara normal.

Zeman (dalam Hastjarjo) ${ }^{8}$ mengkategorisasi tiga arti pokok kesadaran, antara lain (a) kesadaran sebagai kondisi bangun/terjaga (b) kesadaran sebagai pengalaman, serta (c) kesadaran sebagai pikiran (mind). Kesadaran sebagai pikiran digambarkan sebagai keadaan mental yang berisi dengan hal hal proposisional seperti keyakinan, harapan, kekhawatiran, dan keinginan.

Dari sudut pandang yang lain Chalmers (dalam Hastjarjo) ${ }^{9}$ menggolongkan permasalahan kesadaran menjadi dua, permasalahan mudah (easy problems) dan permasalahan sukar (hard problem). Permasalahan mudah kesadaran berkaitan dengan masalah yang secara langsung dapat dipecahkan oleh metode baku ilmu pengetahuan kognitif. Seperti bagaimana otak memadukan

\footnotetext{
7 Tamrin Kamal, “Urgensi Studi Teologi Sosial Islam,” AL Hikmah Jurnal Dakwah Dan Ilmu Komunikasi 2 , no. 1 (2019): 24.

${ }^{8}$ Dicky Hastjarjo, “Sekilas Tentang Kesadaran (Consciousness),” Buletin Psikologi 13, no. 2 (2005): 79-90, https://doi.org/10.22146/bpsi.7478.

${ }^{9}$ Hastjarjo.
} 
informasi yang berasal dari berbagai sumber berbeda dan kemudian menggunakan informasi tersebut untuk mengendalikan perilaku dan bagaimana seseorang mampu menyampaikan kondisi internalnya sendiri. Permasalahan kesadaran yang sukar menyangkut permasalahan pengalaman. Contoh, kita mempunyai kesan yang hidup terhadap bunga-bunga yang berwarna atau sungai dengan air yang jernih; ketika menghirup wangi bunga atau mendengar suara gemericik air, mungkin sejumlah gambaran akan muncul dalam pikiran dan sejumlah emosi akan kita rasakan. Pengalaman-pengalaman tersebut secara bersama membentuk kesadaran, the subjective, inner life of the mind.

\section{Peran Seorang Pelajar dalam Islam}

Peran merupakan terjemahan dari kata role (bahasa Inggris). Secara sosiologis, peran juga dimainkan oleh aktor sosial dalam kehidupannya. Biddle Thomas (dalam Budiarto dan Taher) ${ }^{10}$ mengutarakan peran sebagai seperangkat tingkah laku yang diharapkan oleh orang lain terhadap seseorang dengan kedudukannya dalam suatu tatanan sosial.

Peran sosial merupakan implementasi tugas, hak, dan kewajiban seseorang yang sesuai dengan atau dikonstruksi oleh status sosialnya. Artinya status sosial cenderung akan menentukan peran sosial. Jika seseorang mengerjakan peran sosial selaras dengan statusnya disuatu komunitas, maka orang tersebut sedang memainkan peranannya dalam tatanan sosial.

Terdapat tiga jenis peran sosial. Peran ideal, merupakan peran yang selaras dengan status sosial. Maksudnya peran yang disuguhkan selaras atau cocok dengan harapan umumnya masyarakat. Peran peserta didik adalah belajar, peran dokter adalah mengobati masyarakat yang sakit, dan sebagainya. Jika seorang guru tidak mengajar, berarti ia tidak berperan secara ideal.

Peran yang diinginkan. Merupakan peran yang disuguhkan oleh seseorang berdasarkan keinginannya secara mandiri. Seperti guru yang ingin hadir sebagai sahabat bagi peserta didiknya atau dosen yang ingin menjadi mentor bagi mahasiswanya. Peran-peran tersebut dilaksanakan atas keinginan personal tanpa menjadikan status sosial yang bersangkutan sebagai pertimbangan.

Peran yang dikerjakan. Merupakan peran ideal yang diprioritaskan untuk dieksekusi. Seperti pelajar memilih sebagai seorang peneliti ilmu Ekonomi Islam sebagai peran utama yang dimainkannya. Manusia pada umumnya memiliki status soasial lebih dari satu, sehingga peran yang dilakukan juga banyak. Keadaan tersebut bisa menstimulasi terjadinya konflik peran dalam bentuk ketegangan, kegagalan, atau kesenjangan.

Islam memberikan perhatian besar pada manusia yang berstatus dan berperan sebagai seorang pelajar. Di antaranya tercermin dalam salah satu hadits Rasulullah Saw. yang artinya: Sesungguhnya malaikat meletakkan sayapnya sebagai tanda ridha pada penuntut ilmu. (HR. Ahmad) ${ }^{11}$.

${ }^{10}$ Rahmat Ageng Budiarto and Alamsyah Taher, "Peran Ganda Istri Sebagai Pekerja Buruh Sawit Terhadap Perkembangan Hubungan Sosial Anak (Studi Deskriptif Kualitatif Pada Buruh Perempuan Di Desa Karang Anyar Kecamatan Darul Makmur Kabupaten Nagan Raya)," Jurnal Ilmiah Mahasiswa Fakultas Ilmu Sosial \& Ilmu Politik 3, no. 2 (2018).

${ }^{11}$ Al Imam Abi Hamid Muhammad dan Muhammad Al Ghazali, Ihya 'Ulumuddin, 1, 8th ed. (Darul Kutubil Ilmiyyah, 2017). 
Pelajar memiliki kedudukan yang tinggi karena mereka adalah para pencari ilmu yang diwariskan para utusan Allah Swt. Namun demikian, tidak semua orang yang memiliki status dan peran sebagai seorang pelajar bisa mencapai derajat tinggi tersebut. Untuk mencapainya perlu dipenuhi beberapa sikap/etika yang menjadi kriteria seorang pelajar yang ideal. 10 kriteria seorang pelajar ideal disarikan dari ajaran Imam Al-Ghazali ${ }^{12}$ adalah:

1. Mengutamakan kesucian jiwa dari sifat-sifat tercela.

Mencari ilmu adalah ibadah. Layaknya ibadah shalat yang mensyaratkan kesucian dari hadats, ibadah mencari ilmu pengetahuan pun mensyaratkan kesucian dari berbagai sifat tercela yang sangat mungkin ada dalam jiwa seorang pelajar. Dengan demikian ilmu pengetahuan akan mudah terserap dan tertanam dengan baik.

2. Meminimalisir kesibukan duniawi dan fokus dalam mencari ilmu.

Semakin konsentrasi seorang pelajar dalam belajar, maka semakin besar kemungkinan untuk berhasil dalam bidang yang dipelajarinya. Menghindari aktifitas-aktifitas yang tidak ada kaitannya dengan belajar, terlebih kategori aktifitas yang tidak bermanfaat, adalah keutamaan bagi seorang pelajar.

3. Tidak meremehkan ilmu pengetahuan apapun yang dipelajarinya.

Hal baik apapun yang disampaikan oleh seorang guru, tidak boleh diremehkan oleh seorang pelajar. Bahkan jika yang disampaikan guru tersebut telah dikuasai oleh pelajar. Karena mengulangi (muraja'ah) materi pembelajaran adalah bagian dari aktifitas belajar itu sendiri.

4. Tidak terjebak dalam perbedaan/perseteruan ilmu pengetahuan.

Seorang pelajar seyogyanya menghindari perbedaan-perbedaan perspektif ilmu pengetahuan, sebelum menguasai secara utuh apa yang sedang dipelajarinya. Hal tersebut untuk menghindari kebingungan karena belum memiliki dasar ilmu pengetahuan yang mumpuni. Perbedaan-perbedaan tersebut dapat dipelajari setelah seorang pelajar menguasai perspektif tertentu dengan baik.

5. Tidak menafikan suatu disiplin ilmu apapun.

Telah disadari para ilmuwan bahwa masing-masing disiplin ilmu berkaitan satu sama lain. Kelemahan ilmu pengetahun pada bidang tertentu dapat menghambat seseorang dalam memperdalam ilmu pengetahuan lainnya. Seorang pelajar akan sulit memahami ilmu tafsir tanpa menguasai bahasa Arab misalnya. Ilmu tafsir akan sulit direalisasikan di masyarakat tanpa ditunjang oleh sosiologi, dan begitu seterusnya. Oleh karena itu, tidak semestinya seorang pelajar menafikan suatu disiplin ilmu tertentu

6. Belajar secara bertahap.

Begitu luasnya ilmu pengetahuan yang Allah ciptakan namun begitu terbatasnya kemampuan manusia dalam mempelajari ilmu pengetahuan tersebut. Atas dasar itu seorang pelajar perlu mempelajari berbagai disiplin ilmu pengetahuan secara bertahap.

${ }^{12}$ Ghazali. 
7. Belajar secara sistematis.

Selain bertahap, seorang pelajar perlu menuntut ilmu secara sistematis. Agar pencapaian belajarnya maksimal, peran guru dalam hal ini begitu sentral, yakni mengarahkan dan membimbing pelajar agar sampai pada tujuannya secara tepat waktu dan tepat sasaran.

8. Mengidentifikasi dasar dan manfaat ilmu pengetahuan yang tengah dipelajari.

Untuk meningkatkan motivasi belajarnya, seorang pelajar hendaknya mempelajari terlebih dahulu manfaat ilmu pengetahuan yang akan didalaminya. Hal ini dilakukan agar orientasi belajarnya lebih terarah.

9. Belajar untuk mengisi jiwa dengan kebaikan agar bisa bertaqarrub kepada Allah Swt.

Hakikat belajar adalah menghapus kebodohan/ketidaktahuan yang ada pada diri seorang pelajar. Selanjutnya mengisi jiwanya dengan berbagai kebaikan ilmu pengetahuan. Tujuan akhir dari perjalanan tersebut adalah agar dapat mendekatkan diri kepada Allah Swt.

10. Mengetahui state of the art ilmu pengetahun yang dipelajari.

Sejatinya seorang pelajar dapat membuat peta konsep perjalanan belajarnya. Agar ia mengerti posisi disiplin ilmu yang tengah dipelajarinya dalam peta perjalanan jauhnya dalam mencari ilmu. Hal ini akan membuat kegiatan pembelajaran lebih sistematis dan efektif.

\section{Kesadaran Peran dalam Perspektif Pendidikan Islam}

Status utama manusia di muka bumi adalah sebagai seorang hamba. Maka sebagai implikasinya peran kehambaan adalah peran utama di antara peran-peran lainnya. Kesadaran ilahiyah tersebut telah tertanam dalam fitrahnya, tapi untuk tumbuh perlu dipupuk dengan sentuhan pendidikan Islam, yakni sentuhan pendidikan yang mampu membangun kesadaran diri (self awareness). Kesadaran diri menurut Maharani dan Mustika ${ }^{13}$ dapat didefinisikan sebagai wawasan ke dalam atau wawasan mengenai alasan-alasan dari tingkah laku sendiri atau pemahaman diri sendiri.

Kesadaran selanjutnya yang perlu dibangun oleh manusia adalah kesadaran insaniyah. Setiap manusia hendaknya memiliki status sebagai manusia sholeh secara individu dan sosial. Berperan sebagai individu dengan kepribadian mulia dan menebar manfaat untuk umat manusia lainnya.

Dengan fitrahnya, manusia cenderung pada kesadaran ilahiyah dan insaniyah, namun fitrah tersebut tidak dapat menjamin manusia menjadi orang baik yang diharapkan. Beberapa faktor yang dapat menjadi penyebab manusia berpaling dari fitrahnya adalah melupakan perjanjian dengan Allah Swt, bermaksiat dan tidak menggunakan akalnya dengan maksimal.

Berdasarkan Q.S. Al-Araf ayat 172, setiap manusia sebelum lahir ke dunia pernah dimintai kesaksiannya atas ketauhidan Allah dan mereka mengkonfirmasi eksistensi-Nya dengan baik. Kemudian kesaksian tersebut dibawa manusia hingga lahir ke dunia dalam bentuk fitrah.

${ }^{13}$ Laila Maharani and Meri Mustika, "Hubungan Self Awareness Dengan Kedisiplinan Peserta Didik Kelas VIII Di SMP Wiyatama Bandar Lampung," KONSELI: Jurnal Bimbingan Dan Konseling (E-Journal) 3, no. 1 (2016): 57-62. 
Melupakan atau tidak berusaha mempelajari dan mengingat kesaksian tersebut, berpotensi mendorong manusia untuk lupa akan fitrahnya.

Bermaksiat kepada Allah Swt. Dosa yang terus menerus dilakukan oleh manusia sehingga dapat menutupi hati yang suci. Maka solusi terbaik untuk membersihkan hati adalah dengan cara menjauhi kemaksiatan. Allah berfirman yang artinya: "Sesungguhnya beruntunglah orang yang mensucikan jiwa itu, dan sesungguhnya merugilah orang yang mengotorinya". (Q.S. As-Syams ayat 9-10).

Tidak menggunakan akalnya dengan baik. Selain menegaskan bahwa masalah tauhid adalah fitrah, Al-Qur'an juga berusaha mengajak manusia berpikir dengan akalnya bahwa sangat logis, penciptaan dan keteraturan alam raya dapat menjadi bukti keberadaan Sang Pencipta yang memiliki kekuasaan tanpa batas. Di antaranya dalam surat Ath-Thalaq ayat 12. "Allah lah yang menciptakan tujuh langit dan seperti itu pula bumi. Perintah Allah berlaku padanya, agar kamu mengetahui bahwasanya Allah Maha Kuasa atas segala sesuatu, dan sesungguhnya Ilmu Allah benar-benar meliputi segala sesuatu."

Atas dasar itu, peran pendidikan dalam perspektif Islam berdiri di atas fondasi dan untuk tujuan yang kebenarannya telah terlegitimasi oleh Sang Pencipta manusia. Tidak bersandar pada sesuatu yang relatif. Pendidikan secara umum dapat diartikan sebagai usaha sadar dan terencana untuk mewujudkan suasana dan proses pembelajaran peserta didik untuk mengembangkan potensinya, memiliki kekuatan spiritual keagamaan, pengendalian diri, kepribadian, kecerdasan, akhlak mulia, serta keterampilan yang diperlukan dirinya dan masyarakat. Perspektif Islam pendidikan hadir untuk membantu manusia agar selalu berpegang teguh pada fitrah serta mengembangkannya. Membimbing untuk memperkuat kecenderungannya dalam bertauhid, serta memfasilitasi pengembangan potensinya agar dapat beribadah secara individu dan sosial. Pada akhirnya pendidikan Islam dapat membantu manusia untuk mencapai derajat tertinggi kemanusiaannya, yaitu bertaqwa dan berkompetensi (insan kamil).

\section{Menjadi Hamba Allah adalah Peran Utama Seorang Pelajar}

Allah menciptakan semua makhluk-Nya dengan tujuan tertentu. Hal tersebut didasarkan pada firman-Nya : "Kami tiada menciptakan langit dan bumi dan apa yang ada antara keduanya melainkan dengan (tujuan) yang benar dan dalam waktu yang ditentukan. Dan orang-orang yang kafir berpaling dari apa yang diperingatkan kepada mereka." (Q.S. Al-Ahqaf ayat 3). Termasuk penciptaan manusia, tentu Allah Swt. telah menetapkan tujuannya.

Manusia, termasuk yang berstatus dan berperan sebagai seorang pelajar adalah salah satu makhluk ciptaan Allah Swt. yang dikaruniai perangkat istimewa, yang tidak dimiliki oleh makhluk-makhluk lainnya. Perangkat istimewa tersebut adalah akal untuk berfikir. Dengan akal ia bisa mengenali dirinya, mengenali penciptanya, serta membangun peradabannya. Pertanyaannya, untuk apa makhluk yang dalam Al-Qur'an disebut dengan insan, basyar, nas, tersebut diciptakan?

Merujuk pada Al-Qur'an surat Ath-Thalaq ayat 12, dan surat Adz-Dzariyat ayat 56. Terdapat dua tujuan dari penciptaan manusia. Antara lain untuk mengenal Allah dan beribadah hanya kepada-Nya. 
Urgensi Penguatan Kesadaran Pelajar tentang Perannya sebagai Hamba Allah...

Dera Nugraha, dkk

1. Mengenal Allah

"Allah lah yang menciptakan tujuh langit dan seperti itu pula bumi. Perintah Allah berlaku padanya, agar kamu mengetahui bahwasanya Allah Maha Kuasa atas segala sesuatu, dan sesungguhnya Ilmu Allah benar-benar meliputi segala sesuatu." (QS. AthThalaq ayat 12).

Ayat tersebut secara tersurat memberikan pesan, bahwa penciptaan alam semesta beserta keteraturannya harus mendorong manusia pada kesadaran akan keberadaan, ilmu, dan kekuasaan Allah Swt. Tujuan penciptaan manusia tersebut diatas diperkuat dengan salah satu hadits qudsi yang berarti: "Aku adalah perbendaharaan tersembunyi. Aku ingin dikenal, maka Kuciptakan makhluk." Menurut Syaikh Abdul Qadir Al-Jailani, pernyataan "Aku ingin dikenal" menuntut manusia agar berusaha untuk mengenali-Nya. Allah telah memberi manusia mata fisik untuk mengindera segala hal yang lahir. Memberi juga mata batin (bashîrah) agar manusia bisa melihat hakikat di luar batas pandangan lahir. Apabila bashîrah sudah terbuka, Allah akan membukakan sebagian dari tanda-tanda kekuasaan-Nya yang tidak bisa dilihat dengan mata lahir.

2. Beribadah Kepada Allah

Menyembah Allah Swt. (ibadah) merupakan alasan mengapa manusia diciptakan. Hal tersebut mengacu pada firman-Nya: "Dan tidaklah Aku menciptakan jin dan manusia, melainkan supaya mereka menyembah-Ku." (QS. Adz Dzariyat ayat 56). Juga firman Allah yang terdapat dalam QS. Al-Baqarah ayat 21. "Hai manusia, sembahlah Tuhanmu yang telah menciptakanmu dan orang-orang yang sebelummu, agar kamu bertakwa". Iman Al-Maraghiy berpendapat, bahwa beribadah kepada Allah dapat mengantarkan manusia kepada taqwa. Suatu derajat dimana manusia dapat merasakan kehadiran Allah dalam dirinya, serta memiliki kesadaran ilahiyah yang matang.

Dalam kaitannya peran manusia sebagai hamba dengan tujuan mengibadahi Allah Swt. Yusuf $^{14}$ mengutarakan bahwa kata Ibadullah sudah umum dimaknakan dengan "beribadah" kepada Allah. Secara lebih spesifik diartikan sebagai ketundukpatuhan sang hamba kepada Allah sekurang-kurangnya sebagaimana terakumulasi pada enam rukun iman dan lima rukun Islam.

\section{Fitrah Sebagai Titik Tolak Penguatan Kesadaran Pelajar}

Fitrah secara etimologis dapat diartikan sebagai sifat yang melekat pada sesuatu sejak awal penciptaannya, sifat alami manusia, agama, dan sunnah. Secara istilah banyak tokoh yang mendefinisikan fitrah, di antaranya Al-Qurthubi, Ibnu Katsir, dan Al-Maraghi.

Al-Qurthubi (dalam Saryono) $)^{15}$ memandang fitrah sebagai kesucian jiwa, bahwa manusia sejak lahir dalam keadaan suci tidak memiliki dosa. Ibnu Katsir mengartikan fitrah dengan mengakui keesaan Allah Swt. Manusia sejak lahir membawa tauhid, atau minimal berkecenderungan untuk bertauhid dan berupaya untuk mencapai ketauhidan tersebut. Al-

${ }^{14}$ Burhanuddin Yusuf, "Manusia Dan Amanahnya; Kajian Teologis Berwawasan Lingkungan," Aqidah-Ta : Jurnal Ilmu Aqidah 2, no. 2 (2016): 125-44, https://doi.org/10.24252/aqidahta.v2i2.3439.

${ }^{15}$ Saryono Saryono, “Konsep Fitrah Dalam Perspektif Islam,” Medina-Te: Jurnal Studi Islam 12, no. 2 (2016): $161-74$. 
Maraghi melihat fitrah sebagai kecenderungan untuk menerima kebenaran. Secara fitrah manusia cenderung mencari serta menerima kebenaran, walaupun hanya bersemayam dalam hati kecilnya.

Ibnu Taimiyah (dalam Saryono) ${ }^{16}$ membagi fitrah manusia pada dua macam. Pertama Fitrah Munazzalah, fitrah dari luar yang masuk pada diri manusia berupa petunjuk Al-Qur'an dan As-Sunnah. Digunakan sebagai pengontrol dan pembimbing bagi fitrah Gharizah. Kedua Fitrah Gharizah, fitrah yang terdapat dalam diri manusia yang memberi daya akal. Bermanfaat untuk mengembangkan potensi dasar manusia.

Beberapa definisi lain terkait fitrah manusia adalah: (1) Suci, kesucian dalam jasmani dan rohani. (2) Islam. Abu Hurairah berpendapat bahwa yag dimaksud dengan fitrah adalah agama. Oleh karena itu anak kecil yang meninggal dunia akan masuk surga, karena ia dilahirkan dengan agama Islam, walaupun ia terlahir dari keluarga non muslim. (3) Mengakui keesaan Allah. Manusia lahir dengan membawa kecenderungan bertauhid. (4) Murni (ikhlash). Manusia lahir dengan berbagai sifat, salah satunya keikhlasan dalam beraktifitas. (5) Kecenderungan untuk menerima kebenaran. (6) Potensi dasar manusia sebagai alat utuk mengenal dan mengabdi kepada Allah Swt. (7) Tabiat alami manusia.

Sejatinya strategi pendidikan bertolak sekaligus mengacu pada fitrah yang dimiliki setiap pelajar. Karena pendidikan yang berhasil adalah pendidikan yang mampu menjadikan peserta didiknya menjadi seorang hamba Allah yang taat. Di saat yang bersamaan dapat menjadikan peserta didiknya manusia yang kompeten, berkeahlian untuk berkontribusi dalam membangun kemaslahatan ummat. Hal ini sejalan dengan salah satu kitab KH. Hasyim Asy'ari, adab al-'alim wa al-muta'alim, yang banyak membahas mengenai pendidikan yang menekankan pada masalah pendidikan etika/akhlak dan inti penting dari pemikirannya dalam pendidikan adalah "beribadah kepada Allah Swt". ${ }^{17}$

Pesantren dan madrasah adalah lembaga pendidikan yang melakukan strategi pendidikan tersebut dengan memperkuat kesadaran peserta didik melalui pendidikan tauhid. Pun penting juga untuk diimplementasikan di sekolah umum, karena hal ini terbukti secara efektif menanggulangi perilaku tercela di kalangan pelajar. Di kabupaten Cianjur misalnya, sekolah-sekolah umum mengedepankan Pendidikan Agama untuk menangkal kenakalan remaja. Salah satunya yang dilakukan oleh SMK Anak Muda Siliwangi. ${ }^{18}$ Di sekolah tersebut semua peserta didik diwajibkan mengikuti pembelajaran agama setiap hari seusai melaksanakan salat zuhur di masjid sekolah. Hal itu dilakukan sebagai upaya meningkatkan ketakwaan peserta didik, sehingga secara sadar diharapkan dapat menjauhi berbagai kenakalan remaja.

\footnotetext{
16 Saryono.
}

${ }^{17}$ Ahmad Dwi Nur Khalim, "Urgensi Materi Pembelajaran Akhlak K.H. Hasyim Asy’ari Dalam Menghadapi Tantangan Pembelajaran Abad 21," SCAFFOLDING: Jurnal Pendidikan Islam Dan Multikulturalisme 2, no. 02 (2020): 68-81, https://doi.org/10.37680/scaffolding.v2i02.463.

${ }^{18}$ Admin Cianjur Ekspres, "Melalui Pendidikan Agama Tangkal Siswa Dari Narkoba Dan Tawuran,” January 2020, https://www.cianjurekspres.net/post/5631/melalui-penddidikan-agama-tangkal-siswa-dari-narkoba-dantawuran/ (Diakses 15 Agustus 2020). 


\section{Penutup}

Kesadaran pelajar tentang perannya sebagai hamba Allah akan memberi dorongan kepada mereka dalam melaksanakan kewajiban ibadahnya, sekaligus menghindari perilaku-perilaku tercela. Seperti tidak menghormati orang tua dan guru, tawuran, pergaulan bebas, narkoba, dan sebagainya.

Tujuan Allah menciptakan makhluk-Nya adalah agar manusia mengenali dan beribadah hanya kepada-Nya. Untuk mencapainya, manusia telah dibekali fitrah munazzalah dan fitrah gharizah. Agar fitrah gharizah tumbuh dengan baik, manusia memerlukan dorongan kesadaran atas eksistensinya. Di sanalah ruang bagi proses pendidikan untuk melaksanakan fungsinya.

Dalam perspektif Islam, manusia secara bawaan telah memiliki fitrah yang cenderung memiliki potensi kesadaran ilahiyah dan insaniyah, namun fitrah tersebut tidak dapat menjamin manusia menjadi orang baik dengan sendirinya. Karena alasan beberapa hal, fitrah tersebut bisa tertutupi atau terdominasi oleh hal-hal negatif di sekelilingnya berupa kemaksiatan dan kelalaian. Pendidikan hadir untuk membantu manusia agar selalu berada pada fitrahnya. Membimbing peserta didik diharapkan dapat memperkuat kecenderungannya dalam bertauhid, dan pada gilirannya akan berpengaruh pada perilaku mereka. Termasuk dalam menghindari perilaku tercela.

\section{Referensi}

Admin Cianjur Ekspres. "Melalui Pendidikan Agama Tangkal Siswa Dari Narkoba Dan Tawuran." January 2020, https://www.cianjurekspres.net/post/5631/melalui-penddidikanagama-tangkal-siswa-dari-narkoba-dan-tawuran/ (Diakses 15 Agustus 2020).

Budiarto, Rahmat Ageng, and Alamsyah Taher. "Peran Ganda Istri Sebagai Pekerja Buruh Sawit Terhadap Perkembangan Hubungan Sosial Anak (Studi Deskriptif Kualitatif Pada Buruh Perempuan Di Desa Karang Anyar Kecamatan Darul Makmur Kabupaten Nagan Raya)." Jurnal Ilmiah Mahasiswa Fakultas Ilmu Sosial \& Ilmu Politik 3, no. 2 (2018).

Ghazali, Al Imam Abi Hamid Muhammad dan Muhammad Al. Ihya 'Ulumuddin. 1. 8th ed. Darul Kutubil Ilmiyyah, 2017.

Hanan, Shofira. "Pelajar Dari Tingkat SMP Jadi Peyumbang Bertambahnya Penderita HIV/AIDS." Pikiran Rakyat. September 2018, https://www.pikiran-rakyat.com/jawabarat/pr-01300957/pelajar-dari-tingkat-smp-jadi-peyumbang-bertambahnya-penderitahivaids-429782 (Diakses 22 Agustus 2020).

Hasbi, M. "Konsep Tauhid Sebagai Solusi Problematika Agama Bagi Siswa Madrasah.” Insania 14 No. 2 M, no. 2 (2009): 289-319.

Hastjarjo, Dicky. "Sekilas Tentang Kesadaran (Consciousness)." Buletin Psikologi 13, no. 2 (2005): 79-90. https://doi.org/10.22146/bpsi.7478.

Kamal, Tamrin. "Urgensi Studi Teologi Sosial Islam." AL Hikmah Jurnal Dakwah Dan Ilmu Komunikasi 2, no. 1 (2019): 24.

Khalim, Ahmad Dwi Nur. "Urgensi Materi Pembelajaran Akhlak K.H. Hasyim Asy'ari Dalam Menghadapi Tantangan Pembelajaran Abad 21." SCAFFOLDING: Jurnal Pendidikan Islam $\begin{array}{lllllll}\text { Dan } & \text { Multikulturalisme } & 2, & \text { no. } & 02 & \text { (2020): }\end{array}$ https://doi.org/10.37680/scaffolding.v2i02.463. 
Maharani, Laila, and Meri Mustika. "Hubungan Self Awareness Dengan Kedisiplinan Peserta Didik Kelas VIII Di SMP Wiyatama Bandar Lampung." KONSELI: Jurnal Bimbingan Dan Konseling (E-Journal) 3, no. 1 (2016): 57-62.

Nurfalah, Yasin. "Urgensi Pendidikan Tauhid Dalam Keluarga.” Jurnal Pemikiran Keislaman 25, no. 2 (2014): 338-47. https://doi.org/10.33367/tribakti.v25i2.190.

Ramadhani, Ramadhani. "Pendidikan Akidah Akhlak Sebagai Solusi Pencegahan LGBT." AlAdabiya: Jurnal Kebudayaan Dan Keagamaan 15, no. 01 (2020): 47-68. https://doi.org/10.37680/adabiya.v15i01.223.

Saryono, Saryono. "Konsep Fitrah Dalam Perspektif Islam.” Medina-Te: Jurnal Studi Islam 12, no. 2 (2016): 161-74.

Tobroni, dkk. Memperbincangkan Pemikiran Pendidikan Islam. Prenadamedia Group, 2018.

Yusuf, Burhanuddin. "Manusia Dan Amanahnya; Kajian Teologis Berwawasan Lingkungan." Aqidah-Ta: Jurnal Ilmu Aqidah 2, no. 2 (2016): 125-44. https://doi.org/10.24252/aqidahta.v2i2.3439. 